Across the margins Cultural identity and change in the Atlantic archipelago edited by Glenda Norquay 


\section{Across the margins}

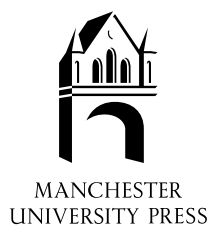

Glenda Norquay and Gerry Smyth - 9781526137227 Downloaded from manchesterhive.com at 04/26/2023 03:58:05AM 
Glenda Norquay and Gerry Smyth - 9781526137227

Downloaded from manchesterhive.com at 04/26/2023 03:58:05AM 


\title{
Across the margins \\ Cultural identity and change in the Atlantic archipelago
}

\author{
EDITED BY GLENDA NORQUAY \\ AND GERRY SMYTH
}

Manchester University Press

Manchester and New York

distributed exclusively in the USA by Palgrave 
Copyright (C) Manchester University Press 2002

While copyright in the volume is vested in Manchester University Press, copyright in individual chapters belongs to their respective authors.

This electronic version has been made freely available under a Creative Commons (CC-BY-NC-ND) licence, which permits non-commercial use, distribution and reproduction provided the author(s) and Manchester University Press are fully cited and no modifications or adaptations are made. Details of the licence can be viewed at https://creativecommons.org/licenses/ by-nc-nd/3.0/

Published by Manchester University Press

Oxford Road, Manchester Mi3 9NR, UK

and Room 400, I75 Fifth Avenue, New York, NY Iooo, USA

www.manchesteruniversitypress.co.uk

British Library Cataloguing-in-Publication Data

A catalogue record for this book is available from the British Library

Library of Congress Cataloging-in-Publication Data applied for

ISBN O 7190 57493

First published 2002

$\begin{array}{llllllllllllllllllll}\text { IO } & 09 & 08 & 07 & 06 & 05 & 04 & 03 & 02 & & \text { IO } & 9 & 8 & 7 & 6 & 5 & 4 & 3 & 2 & \text { I }\end{array}$

Typeset in Caslon and Frutiger Condensed

by Koinonia Ltd, Manchester

Printed in Great Britain

by Bookcraft (Bath) Ltd, Midsomer Norton 